Journal of History Culture and Art Research

Revue des Recherches en Histoire Culture et Art

مجلة البحوث التاريخية و الثقافية والفنية
Vol. 2, No. 2, June 2013

Copyright (C) Karabuk University

http://kutaksam.karabuk.edu.tr/index.php

Özel Sayı / Special Issue

(English Studies)

DOI: 10.7596/taksad.v2i2.221

\title{
Where Dystopia Becomes Reality and Utopia Never Comes
}

\author{
Vesna SULJIC, A. Serdar ÖZTÜRK*
}

\begin{abstract}
The article Where Dystopia Becomes Reality and Utopia Never Comes draws a comparison between utopian and dystopian visions of the world described in two works by Aldous Huxley (1894-1963): Brave New World and Island and a fine line where the author's farsightedness crosses over the boundaries of imagination and turns into reality of the twentyfirst century. Composed as a satire of the world in the 1930s and as a response to H. G. Wells' "utopias of horror", Brave New World displays Huxley's ingenuity in being a sharp and articulate critic of the contemporary society; warning of the dangers of abuse of science in hands of unconstrained establishments of power; and perspicuity of ideologies, mass consumerism, and influences of the media. Prophecies of Brave New World have become realities of our time in many instances, whereas ideals of Island are still in the dreamtime.
\end{abstract}

Keywords: Dystopia, Utopia, Aldous Huxley, Brave New World, Island

\footnotetext{
* International University of Sarajevo
} 


\section{Introduction}

Although they have not been taken seriously by most scholars, science fiction writers appear to be very sharp critics of their time. By situating their stories in the future, they have been drafting realistic images of the contemporary world and consequences that might eventuate from our past, present, or future actions. Neither Aldous Huxley's Brave New World, published in 1932, nor George Orwell's Nineteen Eighty-Four, published in 1949, were regarded believable in the time of their publishing due to the dark, distressing pictures of the future presented in the period when the world healed wounds from the preceding wars. In the second half of the twentieth century, due to the proliferation of Hollywood cinematography drawing on science fiction texts in depicting catastrophic end of the world, either due to an alien intervention, abuse of technology by humans, or natural causes, the science-fiction genre has been viewed as mostly entertaining and light. The plot would frequently be weak, with an ordinary (usually American) citizen playing a hero who saves the world. Nevertheless, the sociological, cultural, political, economic, or psychological concerns presented in the science fiction literature should not be regarded perfunctory since a lot of issues once rebutted have proven realistic. In this essay, I will examine two works by Aldous Huxley, Brave New World, (1932), and Island (1962), to demonstrate instances where a dystopian view of the world, once deemed improbable and uttermost fantastic, has become part of our reality, and suggest reasons why utopian ideas, overly hopeful and buoyant, could not be accomplished yet.

Both works could be classified as fantasy, due to their "deliberate presentation of improbabilities through any one of four methods - the use of unverifiable time, place, characters, or devices - to a typical reader within a culture whose level of sophistication will enable the reader to recognize the improbabilities" (Schmerl, 328). However, Brave New World, preceding Island by thirty years, is more scientific than fictional, more realistic than improbable. Its placement into the category of dystopian literature is largely due to the dehumanized view of the futuristic society in which humans are genetically engineered to respond to requirements of the ruling ideologies. The first publication of Brave New World occurred merely fourteen years after the First World War had ended, in the midst of great economic and social turbulences in the USA and Western Europe, the rise of fascism in Italy and Germany, and strengthening of totalitarian socialism in the Soviet Union. Scientific advances were most prominent in natural sciences. 
Initially, not all critics regarded Huxley as a far-thinker and a serious social critic. He was accused of borrowing ideas for Brave New World from Joyce or T. S. Eliott, and one of the critics concluded a negative review by saying that "it is better to recover one's sense of proportion and be grateful for the pleasure and entertainment Huxley's novels have given - so long as one does not take him too seriously as a novelist." (Bald, 185) It has also been suggested that the story related to Evgeny Zamiatin's We, which had been translated from Czech into English in 1924 (Schmerl, 1962). Huxley himself admitted that in Brave New World he wanted to parody H. G. Wells and his utopias (Woiak, 2007). As Semmler (1970) suggests, H. G. Wells believed that science would empower men and lead them away from ignorance, superstition, poverty, to a happy life on earth; Huxley, on the contrary, implied in Brave New World that such assumptions could not be probable. In 1949, he bitterly concluded that due to achievements made in the scientific fields, which also led to and accounted for an unprecedented destruction of civilizational structures, values and human lives, he was much closer to the bleak vision of the future than Orwell was in Nineteen Eighty-Four.

Aldous Huxley was "bred in an intellectual and scholastic purple" (Semmler, 1970) which included a famous grandfather, Thomas Henry Huxley, philosopher and one of the fervent Darwin's students, who believed that there had been a conflict between the universal forces of natural selection and the ethics of the humane intervention in artificial selection of the fittest (Schmerl, 1962); younger brother Julian, a world-famous biologist and one of the advocates of eugenics; and a half-brother, Professor Andrew Fielding Huxley, who shared the 1963 Nobel Prize for Physiology and Medicine (Semmler, 1970). Educated at Eton and Oxford, inquisitive, determined, and well informed in scientific advancements of his time, Aldous Huxley observed the rapid changes in political ideologies, science and culture, and speculated about their future outcomes in relation to those who held the power.

How radical Huxley's ideas were should not be surprising considering that he was one of the supporters, although never an activist, of the British 1920s-1930s eugenics movement which favoured higher birthrates among the intellectual elite on the expense of sterilization of the lower social classes deemed as inheriting less developed mental faculties (Woiak, 2007). These ideas are used in both Brave New World and Island to ascertain the need for change of the human race for the better by artificial selection. Woiak argues that "the social class prejudice was always the predominant factor in British eugenics, and Huxley was clearly in the mainstream" (123), which is projected in the caste system of Brave New World where the classes are discriminated against being "Gammas, Deltas, and Epsilons" of mass production, or favoured as "Alpha and Beta" 
intellectuals, with subclasses of "Plus" or "Minus" in each category. The ideology behind it is that people should be made to like their social destiny which they cannot escape; to be obedient, servile dots in a mosaic; to work for a communal good; or for a higher Being. In line with the British eugenics that promoted that the lower class inherited lower intelligence, Huxley concludes that "an Epsilon embryo must have an Epsilon environment as well as Epsilon heredity" (Brave New World, 8). In accord with the same principle of selection, the practice of artificial insemination, performed on the island of Pala in Island, is used to protect the inhabitants from hereditary diseases and to improve the race. The "better quality" individuals are selected to donate sperm, and it is up to the parents to decide whether they want to have a genetically selected child or not, contrary to practices in Brave New World, where the government controls the production of genetically engineered population.

Utopian or dystopian visions in 1932 or 1962 respectively, human in vitro fertilization became a reality in the 1970s. Nowadays, IVF procedures and surrogate mothers have become common practices around the world, supported by national legislations granting the right to the individual to opt for a method of having a child. Scientific advances in the last decades in biotechnologies are consequently closely linked to the importance of social responsibility of the science. There is a plethora of ethical dilemmas regarding the impact of the scientific research and its social consequences on the human genome project and all the possible manipulations with the genetic material - from the better to the worse. On May 16, 2013, an article New Stem Cell 'Milestone" Revealed appeared in The Australian online asserting that "it employs a cloning technique [which] is certain to fuel controversy over "Brave New World" science." (www.theaustralian.com.au)

One of the concerns Huxley had and which he expressed in Brave New World Revisited published in 1958, the sequel to Brave New World, was that the future would not be the age of space explorations, but the age in which the world would be faced with over-population (Watt 1968). In the "utopian" Island, population growth is controlled by contraceptives which are free, tax deductable, and easily accessible like education, while for others there is "maithuna", a yoga technique of love making which exercises sexual restraint. On the other hand, due to the strict controllable mechanism of producing embryos in Brave New World, over-population cannot be a matter of concern in the World State. Besides, only thirty percent of females are fertile, and since it is socially abhorrent to bear children anyway, contraceptives are implied. Huxley was mostly focused on conditioning of human embryos, while not considering the production of bioengineered animal or plant species to equalize with the growth of human population. 
Huxley's prediction of a population increase has turned true. It is not, however, that there is a lack of resources in the world; however, the distribution of resources is wrong. The former colonists who built their empires on the colonized still hold shares in the wealth of those they once ruled upon - either in form of high bank interests, unfavourable trade contracts, by supporting political instability, or creating unrest. The rich become richer and have excess of resources. The former colonies, on the other hand, instead of building their states through development of industry, education, or culture, fall into more and more debts to pay off the interests on the loans thus becoming more and more dependent on their former masters. Natural balance is not in the number of bodies that share the planet, but in the way how they co-exist.

Yet, not all aspects of both works are within the frame of dystopia. On the contrary, the notions of eternal happiness, stability, economic independence, sustainability, absence of poverty, or eradication of diseases, are all ideals that humanity has been striving for. In Island, education and self-government of individuals are provided as key elements of improvement of a community. The utopian world of Pala is a meeting point between two cultures - the Western one, represented by the founder of the Palanese economic sustainability and democratic system, a Scottish doctor Andrew MacPhail, and the Eastern one, symbolized by the old Raja, which recognizes the value of spiritualism, training of mind and body, and individual freedom. There is an awareness of the individual and the social responsibility towards the life on the planet in general. Science and religion are combined so that each individual can search for and reach the inner self. Buddhists believe in eternal life, and our passage through this life should be filled with good behaviour, good deeds, peaceful living, or else, in our "next life" we will suffer consequences from our wrongdoings and our bad karma will continue for several lives until we purify ourselves by being good - moral, caring, compassionate. Everyone is responsible for their own actions and only through spiritual and material chastity one can expect to finally reach the ultimate goal - light and eternal life.

Since moving to the USA in 1937, Huxley became involved in practising Buddhism. In Island, he illustrates advantages of building a community on the politics of goodness, instead of the power. The Palanese are Mahayanist Buddhists, but they do not exclude other religions. Various Eastern philosophies are represented in their teachings - from Taoism, Buddhism, to Hinduism. The crucial dystopian element in Island is when despite all the benevolence of its inhabitants, Pala's ideal society is destroyed in one single night. The evil in form of "the great world of impersonal forces and proliferating numbers of collective paranoias and organized diabolism" wins (353-354). 
Furthermore, in Brave New World, the highest principles are peace, stability, discipline, and organization of work according to one's abilities. However, the methods of accomplishing such high social goals - such as, genetic engineering for the sole purpose of providing human bodies for the state's requirements for mass production and consumption - are gruesome and dystopian.

Huxley recognized the avarice of the big industries symbolized by Ford, the founder of the World State in Brave New World, or by big oil companies competing to exploit resources and thus destabilize the government, eventually aiding the coup d'etat in Island; he also acutely noticed the uncontrollable expansion of the mass consumerism, aided by the mass media and advertising, creating a vicious circle of constant creation of need for supply. Like citizens of the World State in Brave New World who are stimulated through hypnopaedia methods to desire new products and discard the worn ones, "ending is better than mending; the more stitches, the less riches" (23), eighty years after the publishing of the novel, the "riches" suffocate in excess, whereas the poor ("liberated") countries are used as landfill areas. Huxley satirizes the world of the late 1920s and early 1930s; nevertheless, his exaggerated vision of the future is upsettingly similar to our world today.

It is probable that Huxley believed that hallucinogenic substances can assist in creating better communities. He openly experimented with mescalin, LSD, and other drugs in 1950s and documented his experiences in 1953 in The Doors of Perception, a work popular in the heyday of the "drug culture" of the 1960s, which also inspired Jim Morrison to name his later very famous rock band The Doors (Holoka, 1982). However, Huxley confessed that man's will suffers a profound change despite the seemingly unimpaired mental faculties. It is thus beyond any doubt that neither soma in Brave New World nor moksha medicine in Island could improve the society through the life of individuals. In both utopian societies, the drug is used to mask the reality.

"Before Ford, people used to take morphium and cocaine. But in A.F. 178, 2000 pharmacologists and bio-chemists were subsidized. In A.F. 184, it was being produced commercially. The perfect drug. Euphoric, narcotic, pleasantly hallucinant. It had all the advantages of Christianity and alcohol, but none of their defects." (Brave New World, 25)

It is therefore a dystopian element in both works which leads to the conclusion that happiness cannot be achieved through one's self-fulfillment, creativity, education, but through chemical substitution. In Island, the children are given pills to control their personality. In the 
climax of the novel, Will Farnaby's experience with moksha medicine starts around midnight, and the experiment is meant to bring him to the level of transcendence to the eternal truth and light; however, he remains oblivious that the Rendang military action kills the society of the pacifist Palanese.

Then again, Huxley's prophecy that social stability would depend on drugs has proven correct since pharmaceutical industry has monopoly over our health and in the places where most inhabitants depend on some form of drug - be it antidepressant or sedative - it is unlikely that anyone would question anything and the society would remain stable, unless the supply of drugs decreases. Valium (diazepam) was discovered in 1960, marketed in 1963, and rapidly became the most prescribed drug in history (www.meducation.net/resources). Further discoveries in chemistry and biology resulted in Fluoxetine (Prozac), which thanks to dramatically changed marketing strategies in the 1990s and the Internet, became another bestseller of the pharmaceutical industry. According to Inside the Pharmaceutical Industry - Deceptive Marketing Scheme, a TV documentary presented on www.insiderexclusive.com, nowadays, the pharmaceutical industry makes more than $\$ 650$ billion a year, with the expected reach of $\$ 734$ billion at the end of 2013, with the largest markets in the USA, Europe and Japan. The main objective of such multinational giants is profit. The companies' endeavours to make that extra profit leads to aggressive marketing to increase the people's already excessive consumption of medicines, including antidepressants, which further leads to more apathy and "stability" of the community.

As a critic of society, and as a man of letters, Huxley bitterly satirized the way popular culture was taking its direction towards superficiality, vulgarity and standardization. He referred to the values and moral life of the nation as directly connected with the arts, among which music is one of the most important. Although not formally musically educated, Huxley appreciated music and admitted that while he was listening to classical works he had learned a lot about art in general. (Aplin 1983) In the early 1920s, he worked as a freelance journalist and a music critic for the Weekly Westminster Gazette. He had initial interest in jazz while he was a student in Oxford, however he despised it for its sensuality and cheapness, so he mainly reviewed concerts of classical music. He regarded Beethoven and Brahms very highly, but did not have a prophetic inkling for Stravinsky's or Bartok's music. In Brave New World, there is "no leisure from pleasure"(26) and each individual enjoys synthetic music, plays with Centrifugal Bumble puppies, and goes to the cinema ("feelies") to experience tactual effects. The pleasure is only physical, thus citizens are encouraged to be promiscuous because the state policy defines that 
"everyone belongs to everyone else". There is virtually no creativity, aesthetics, emotions, just consumption. Everything is so clean and hygienic and the past is eradicated like diseases, so even scents, strong triggers of memories and past experiences, serve only as symbols of pleasure and beauty. "Big Government must sell a political ideal; Big Business in the democracies must sell products, not as products, but as symbols of something else, beauty or power." (Dantzich, 1959, 116) Or, as Huxley put it in Brave New World, "you can't consume much if you sit still and read books" (23), so the purpose of books is limited to instructions manuals and reading for other purposes is non-existent. There is stability, though; protagonists remain constant throughout their lifetime. The progress is halted and limited only to the survival. There is no thinking, reading, religion, not even retirement. The only purpose in life is to be, to stay alive. Religions of the "Pre-Ford" era, are substituted by rituals and ceremonies pertaining to worshipping another God-like figure, as in "I drink to the Greater Being", or "I drink to the imminence of his Coming" (35), all of which are resonant to the church practices at the communion or after the mass in Christianity. Furthermore, Ford Day's celebrations, Community Sings, and Solidarity Services, all add to the Ford idolatry exhibited by the servile citizens of Brave New World.

The destruction of culture in the attitude "art for everybody, nobody for the art" is noticeable today in the celebrity status of ordinary artists, whose worth is denominated in million-dollar contracts; in plethora of works in visual arts, music, or literature which cannot stand the test of time longer than a few years; in destruction of historical monuments. A sad example of Huxley's prophecies nowadays is the position of art and culture in Bosnia and Herzegovina, where due to the political institutions' lack of cultural awareness, or at least appreciation of their historical significance, National Museum closed down in October 2012, after 124 years of existence. The financial and moral crises acutely affect most of other cultural institutions in the country. (www.cultureshutdown.net) Mass production of cheap, vulgar, simplified "culture" supercedes creative, profound, meaningful arts. It is not Huxley's dystopia any more that "not philosophers but fret-sawyers and stamp collectors compose the backbone of society" (Brave New World, 2). It is our reality.

In tradition of the English literature, Huxley names protagonists after certain qualities they possess, or after the leading political or scientific contemporaries he satirizes. A rebellious young radical from Psychology Bureau, an Alpha plus, is called Bernard Marx; a Gamma doxy is named Lenina Crowne; a little girl playing erotic games is Polly Trotsky. However, most critics of initial reviews regarded the novel as "a little joke" (Woiak 2007, 111), disregarding its 
bitter condemnation of the totalitarian regimes, manipulation with scientists, or dangers of abuse of science in Huxley's, or any future time.

Huxley appreciated the work of Alfred Mond, the industrialist who contributed to better efficiency and rationalization of the British chemical industry in 1926 (Woiak, 2007) and the only person who has access to the books of the Pre-Ford Era in Brave New World is Mustapha Mond, one of the ten World State Controllers, in charge of the West Europe. By selecting this name for the powerful controller, Huxley might have intended to show appreciation for the Oriental, or Arabic cultures, and the wealth of their philosophical and literary traditions. Paradoxically, the only person who Mustapha Mond can share his knowledge of literature and philosophy with is a savage, a self-educated human born in a humiliating manner by a viviparous mother, and who learned to read in a remote Indian Reservate in New Mexico. Mustapha Mond has not lost the touch with reality thanks to the connection with the past; nevertheless, all the world's intellectual treasure is kept locked under his auspices, thus it becomes worthless.

Huxley's Anglo-centric orientation is noticeable as it is London where Brave New World is happening; it is English language that is used for communication (Polish, German, or French are dead languages, for instance); it is Shakespeare's collected works that John the Savage reads. Even in the idealistic Palanese community in Island, citizens go abroad to England to get education; their native language is used for casual conversations and English in formal situations. Political, financial, scientific or cultural impacts of the British and American dominance in the twentieth century are still noticeable; nevertheless, other competing nations are the forces that Mustapha Mond could have represented. In Brave New World he is one of ten world controllers. Who are the world controllers today? G-8 plus European Commission and European Council, which makes (at least these) ten world controllers.

Another dystopian element which became our reality and nightmare is the loss of identity. Huxley prophesied in Brave New World that man's identity would be reduced to the person's identification number on the bottle containing the embryo. Two billion inhabitants share only ten thousand names, Crowne being one of them, shared by two protagonists, Lenina and Fanny (16). The London Hatchery Centre produces thousands of clones each year. People are sub-classed genetically and also by colour of their clothing. The satirical State's motto at the entrance of Central London Hatchery and Conditioning Centre, Community, Identity, Stability, suggests that this edifice is moral, just, advanced, tailored to suit the community. 
In our modern cyber world, our personal data are virtually shared by numerous marketing companies, mostly unknown to us, and in many instances our ID number is given precedence to our first or family name. Social networks on the Internet not only share the information about our professional and private life, but also fabricate the data pertaining to our political, sexual, religious or other preferences or engagements, creating false identification and causing a multitude of inconveniences or possible legal implications.

In conclusion, what was considered fiction and put aside on the same shelf with the Brother Grimm's tales in 1930s has become part of our lives in the twenty-first century. Fortunately, not all the darkest predictions have come true. People are not predestined who they will become by a bottled formula. We do have opportunities to choose what kind of career we want to pursue. We still speak different languages of the world. Furthermore, most countries do not have tyrannical rulers who abominably oppress their citizens. Yet, one has to be wary whether human imagination is unlimited as to foresee what could happen in the future; or, is it because of what has been foretold that we strive to make it? Why is the dystopian vision more accurate and why is the utopia so unreachable? A possible answer to this conundrum is that we construct what we most fear, and keep dreaming of what we desire the most. Island remains in the realm of the desired, albeit unachievable, due to more powerful destructive forces reigning over man's idealistic ambitions. Human kind has travelled a great distance in technological direction so far; however, on the journey to understand the inner self and make it close to highly desirable perfection, it has only made a few paces.

\section{Bibliography}

Aplin, John. "Aldous Huxley and Music in the 1920s". Music \& Letters, Vol. 64, No. 1/2 (Jan. - Apr., 1983) pp. 25-36. JSTOR., on 25/04/2013, http//www.jstor.org

Bald, R.C. "Aldous Huxley as a Borrower". College English, Vol. 11, No.4 (Jan., 1950), pp. 183-187. JSTOR., on 25/04/2013, http//www.jstor.org

Dantzich, S.van. "Brave New World Revisited by Aldous Huxley". The Australian Quarterly, Vol.31, No.4 (Dec., 1959), pp.115-118. JSTOR., on 25/04/2013, http//www.jstor.org 
Holoka, James P. "Aldous Huxley and the Lotus Experience". The Classical World, Vol. 76, No.1 (Sep. - Oct., 1982), pp. 39-41. JSTOR., on 25/04/2013, http//www.jstor.org

Huxley, Aldous. Brave New World. e-book

Huxley, Aldous. Brave New World (Chatto and Windus). Translated into Serbian as Vrli novi svet. Libretto. Beograd, 2009.

Huxley, Aldous. Island. www.huxley.net/island

Huxley, Aldous. Island (Chatto and Windus, London, 1975). Translated into Croatian as Otok. August Cesarec. Zagreb, 1985.

Rabkin, Eric S. "Science Fiction and the Future of Criticism". PMLA, Vol. 119, No.3, Special Topic: Science Fiction and Literary Studies: The Next Millenium (May, 2004), pp. 457-473. JSTOR., on 11/03/2013, http//www.jstor.org

Schmerl, Rudolf B. "The Two Future Worlds of Aldous Huxley". PMLA, Vol.77, Np.3 (Jun., 1962), pp. 328-334. JSTOR., on 25/04/2013, http//www.jstor.org

Semmler, Clement. "Aldous Huxley Revisited". The Australian Quarterly, Vol.42, No.4 (Dec., 1970), pp. 74-82. JSTOR., on 25/04/2013, http//www.jstor.org

Watt, Donald J. "Vision and Symbol in Aldous Huxley's Island. Twentieth Century Literature, Vol. 14, No.3 (Oct.,1968), pp. 149-160. JSTOR., on 25/04/2013, http//www.jstor.org

Woiak, Joanne. "Designing a Brave New World: Eugenics, Politics, and Fiction”. The Public Historian, Vol.29, No.3 (Summer 2007), pp. 105-129. JSTOR., on 14/03/2013, http//www.jstor.org

www.cultureshutdown.net

www.insiderexclusive.com/justice-in-america/inside-the-pharmaceutical-industry-deceptivemarketing-scheme/

http://www.theaustralian.com.au/news/breaking-news/new-stem-cell-milestone-revealed/storyfn3dxix6-1226644093976 